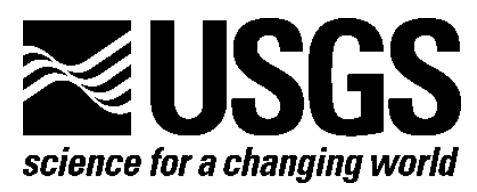

\title{
Central Appalachian Basin Natural Gas Database: Distribution, Composition, and Origin of Natural Gases
}

By Yomayra A. Román-Colón and Leslie F. Ruppert

Open-File Report 2014-1207

U.S. Department of the Interior

U.S. Geological Survey 


\section{U.S. Department of the Interior \\ SALLY JEWELL, Secretary}

\section{U.S. Geological Survey \\ Suzette M. Kimball, Acting Director}

U.S. Geological Survey, Reston, Virginia: 2014

For more information on the USGS — the Federal source for science about the Earth,

its natural and living resources, natural hazards, and the environment-visit

http://www.usgs.gov or call 1-888-ASK-USGS

For an overview of USGS information products, including maps, imagery, and publications, visit $h$ ttp://www.usgs.gov/pubprod

To order this and other USGS information products, visit $h$ ttp://store.usgs.gov

Any use of trade, product, or firm names is for descriptive purposes only and does not imply endorsement by the U.S. Government.

This database, identified as "Central Appalachian basin natural gas database," has been approved for release and publication by the U.S. Geological Survey (USGS). Although this database has been subjected to rigorous review and is substantially complete, the USGS reserves the right to revise the data pursuant to further analysis and review. Furthermore, it is released on condition that neither the USGS nor the U.S. Government may be held liable for any damages resulting from its authorized or unauthorized use.

Although this report is in the public domain, permission must be secured from the individual copyright owners to reproduce any copyrighted material contained within this report.

Suggested citation:

Colón-Román, Y.A., and Ruppert, L.F., 2014, Central Appalachian basin natural gas database-Distribution, composition, and origin of natural gases: U.S. Geological Survey Open-File Report 2014-1207, 13 p., 1 app., http://dx.doi.org/10.3133/ofr20141207.

ISSN 2331-1258 (online) 


\section{Contents}

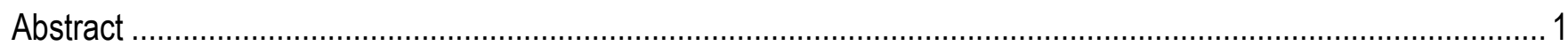

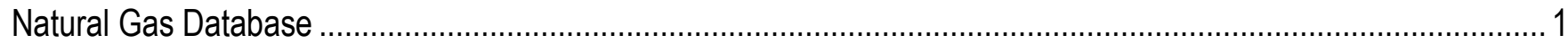

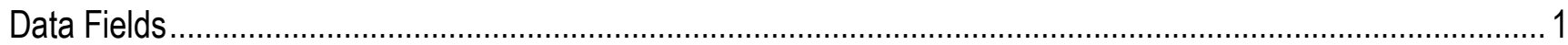

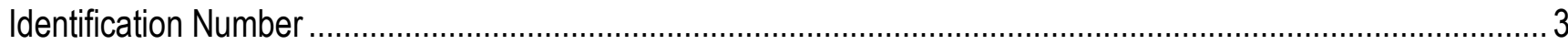

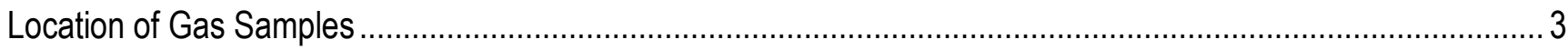

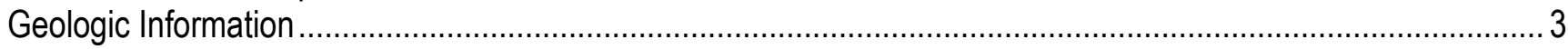

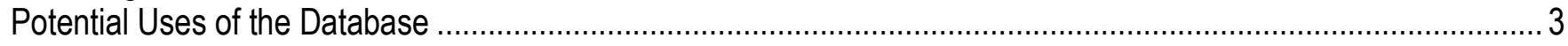

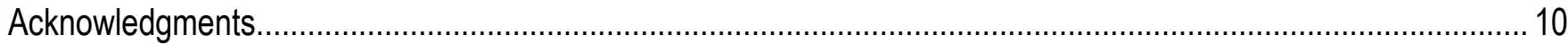

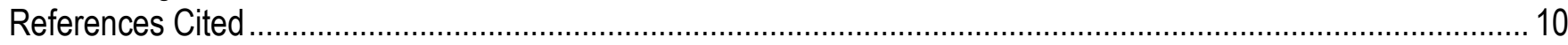

Appendix 1. Natural_Gas_Geochemical_Database_2013 ........................................................................... 13

\section{Figures}

Figure 1. Map of the distribution of methane content in Cambrian to Pennsylvanian natural-gas-producing formations in the central Appalachian basin from the natural gas database

Figure 2. Map of the distribution of methane content in Devonian natural-gas-producing formations in the central Appalachian basin from the natural gas database

Figure 3. Map of the distribution of methane content in Silurian natual-gas-producing formations in the central Appalachian basin from the natural gas database

Figure 4. Map of the distribution of carbon dioxide in Cambrian to Pennsylvanian natural-gas-producing formations in the central Appalachian basin from the natural gas database... 8

Figure 5. Map of the distribution of isotopic measurements contained in the database 9

\section{Table}

Table 1. Ranges of natural gas compositions, in percent, for the 1,280 analyses from the "Molecular Compositions" worksheet. 


\section{Conversion Factors}

\begin{tabular}{lcl}
\hline Multiply & By & To obtain \\
\hline foot $(\mathrm{ft})$ & Length & \\
\hline & 0.3048 & meter $(\mathrm{m})$ \\
\hline cubic foot $\left(\mathrm{ft}^{3}\right)$ & Volume & \\
\hline & 0.02832 & cubic meter $\left(\mathrm{m}^{3}\right)$ \\
\hline pound per square inch gauge $\left(\mathrm{lb} / \mathrm{in}^{2}\right)$ & Pressure & \\
\hline
\end{tabular}

Horizontal coordinate information is referenced to the North American Datum of 1983 (NAD 83).

Stable isotope ratios are given in per mil (\%). 


\title{
Central Appalachian Basin Natural Gas Database: Distribution, Composition, and Origin of Natural Gases
}

\author{
By Yomayra A. Román-Colón and Leslie F. Ruppert
}

\begin{abstract}
The U.S. Geological Survey (USGS) has compiled a database consisting of three worksheets of central Appalachian basin natural gas analyses and isotopic compositions from published and unpublished sources of 1,282 gas samples from Kentucky, Maryland, New York, Ohio, Pennsylvania, Tennessee, Virginia, and West Virginia. The database includes field and reservoir names, well and State identification number, selected geologic reservoir properties, and the composition of natural gases (methane; ethane; propane; butane, iso-butane [i-butane]; normal butane [ $n$-butane]; iso-pentane $[i$ pentane]; normal pentane [ $n$-pentane]; cyclohexane, and hexanes). In the first worksheet, location and American Petroleum Institute (API) numbers from public or published sources are provided for 1,231 of the 1,282 gas samples. A second worksheet of 186 gas samples was compiled from published sources and augmented with public location information and contains carbon, hydrogen, and nitrogen isotopic measurements of natural gas. The third worksheet is a key for all abbreviations in the database. The database can be used to better constrain the stratigraphic distribution, composition, and origin of natural gas in the central Appalachian basin.
\end{abstract}

\section{Natural Gas Database}

This report describes and makes available a U.S. Geological Survey (USGS) database, which contains data on molecular and isotopic composition of natural gas in the central Appalachian basin of the United States. Published and unpublished sources were used to compile data for 1,282 gas samples from Kentucky, Maryland, New York, Ohio, Pennsylvania, Tennessee, Virginia, and West Virginia. The database can be used to better constrain the stratigraphic distribution, composition, and origin of natural gas in the central Appalachian basin.

\section{Data Fields}

The central Appalachian basin natural gas geochemistry database is a spreadsheet consisting of three worksheets in Microsoft ${ }^{\circledR}$ Excel 2010 format (appendix 1). The first worksheet, titled "Molecular Compositions," contains 72 fields describing 1,280 gas samples with their well names, well information, and geologic information including producing strata and stratigraphy. The content and composition of natural gas in mole percent (\%) for all of the samples are provided in the worksheet (appendix 1). 
A total of 1,231 sample locations and American Petroleum Institute (API) identification numbers are provided for the gas samples. Location and API numbers were obtained from published sources and augmented by public information from a variety of sources, including Charles Threlkeld (data included in U.S. Geological Survey, 2009), Kentucky Geological Survey (2012), Ohio Department of Natural Resources (2012), Tennessee Division of Geology's Electronic oil and gas database (2008), U.S. Environmental Protection Agency (2012), USGS National Geologic Map Database (2012), Virginia Department of Mines, Minerals and Energy (2012), West Virginia Geological and Economic Survey (2012), New York Department of Environmental Conservation (2011), Pennsylvania Department of Natural Resources (2011), and R.T. Ryder (U.S. Geological Survey, written commun., 2011).

The natural gas database contains analytical data on eight hydrocarbons: methane $\left(\mathrm{CH}_{4}, \mathrm{C}_{1}\right)$; ethane $\left(\mathrm{C}_{2} \mathrm{H}_{6}, \mathrm{C}_{2}\right)$; propane $\left(\mathrm{C}_{3} \mathrm{H}_{8}, \mathrm{C}_{3}\right)$; normal butane (or $n$-butane; $\mathrm{nC}_{4} \mathrm{H}_{10}, \mathrm{nC}_{4}$ ); iso-butane (or $i$ butane; $\left.\mathrm{iC}_{4} \mathrm{H}_{10}, \mathrm{iC}_{4}\right)$ or butane $\left(\mathrm{iC}_{4} \mathrm{H}_{10}\right)$, if the class was not specified in the original report; normal pentane (or $n$-pentane; $\mathrm{nC}_{5} \mathrm{H}_{12}, \mathrm{nC}_{5}$ ); iso-pentane (or $i$-pentane; $\mathrm{iC}_{5} \mathrm{H}_{12}, \mathrm{iC}_{5}$ ); hexane $\left(\mathrm{C}_{6} \mathrm{H}_{14}, \mathrm{C}_{6}\right.$ ); cyclopentane $\left(\mathrm{C}_{5} \mathrm{H}_{10}\right)$; and one compound class of hexanes $\left(\mathrm{C}_{6+} \mathrm{H}_{14}, \mathrm{C}_{6}, \mathrm{C}_{6+}\right)$. See table 1 for the number of samples of each hydrocarbon that are included in the database. The natural gas database also contains analytical information on the non-hydrocarbon gases nitrogen $\left(\mathrm{N}_{2}\right)$, oxygen $\left(\mathrm{O}_{2}\right)$, argon $(\mathrm{Ar})$ carbon dioxide $\left(\mathrm{CO}_{2}\right)$, hydrogen $\left(\mathrm{H}_{2}\right)$, helium $(\mathrm{He})$, and hydrogen sulfide $\left(\mathrm{H}_{2} \mathrm{~S}\right)$. See table 1 for the number of samples of each non-hydrocarbon gas included in the database.

Table 1. Ranges of natural gas compositions, in percent, for the 1,280 analyses from the "Molecular Compositions" worksheet.

[There was no attempt to remove results that were reported as zero in the original reports. However, the user should consider using the zero values with caution because it is not known whether the gas was analyzed and the component was not detected or whether no attempt was made to analyze the component.]

\begin{tabular}{|l|c|c|c|c|}
\hline \multicolumn{1}{|c|}{ Gas } & $\begin{array}{c}\text { No. of } \\
\text { analyses }\end{array}$ & $\begin{array}{c}\text { Range } \\
\text { (in percent) }\end{array}$ & $\begin{array}{c}\text { No. of analyses } \\
\text { with "0" gas }\end{array}$ & $\begin{array}{c}\text { No. of analyses } \\
\text { labeled "trace" }\end{array}$ \\
\hline Methane & 1,267 & $1.2-99.4$ & 3 & 0 \\
\hline Ethane & 1,262 & $0.01-64.7$ & 4 & 23 \\
\hline Propane & 1,120 & $0.001-16.2$ & 19 & 25 \\
\hline $\boldsymbol{n}$-butane & 993 & $0.0010-5.6$ & 205 & 57 \\
\hline $\boldsymbol{i}$-butane & 854 & $0.0012-3.1$ & 221 & 100 \\
\hline $\boldsymbol{n}$-pentane & 987 & $0.0019-2.0000$ & 285 & 113 \\
\hline $\boldsymbol{i}$-pentane & 602 & $0.0049-1.4$ & 254 & 401 \\
\hline Cyclohexane & 791 & $0.1-0.7$ & 213 & 44 \\
\hline Hexane and Hexane plus & 794 & $0.0011-1.5$ & 245 & 3 \\
\hline Nitrogen & 1,218 & $0.1-78.1$ & 22 & 212 \\
\hline Oxygen & 435 & $0.0056-21.35$ & 407 & 502 \\
\hline Argon & 59 & $0.003-1.9$ & 270 & 94 \\
\hline Hydrogen & 300 & $0.0021-2.27$ & 451 & 1 \\
\hline Hydrogen sulfide & 2 & $0.0260-0.51$ & 957 & 188 \\
\hline Carbon dioxide & 1,236 & $0.0099-1.080$ & 4 & 209 \\
\hline Helium & & & & 0 \\
\hline
\end{tabular}


The second worksheet, titled "Isotopic Compositions," contains 50 fields describing 186 natural gas samples with accompanying carbon and deuterium isotopic data for methane $\left(\delta^{13} \mathrm{C}_{1}\right)$, deuterium in methane $\left(\delta^{2} \mathrm{HC}_{1}\right)$, ethane $\left(\delta^{13} \mathrm{C}_{2}\right)$, deuterium in ethane $\left(\delta^{2} \mathrm{HC}_{2},\right)$, propane $\left(\delta^{13} \mathrm{C}_{3}\right)$, deuterium in propane $\left(\delta^{2} \mathrm{HC}_{3}\right), i$-butane $\left(\delta^{13} \mathrm{C}_{i}-\mathrm{C}_{4}\right), n$-butane $\left(\delta^{13} \mathrm{C}_{n}-\mathrm{C}_{4}\right), n$-pentane $\left(\delta^{13} \mathrm{C}_{n}-\mathrm{C}_{5}\right)$, butane $\left(\delta^{13} \mathrm{C}_{4}\right)$, and carbon dioxide $\left(\delta^{13} \mathrm{CO}_{2}\right)$ reported in mole percent and percent (appendix 1, worksheet 2). Included are five nitrogen $\left(\delta^{15} \mathrm{~N}\right)$ isotopic analyses. Isotopic data were obtained from Burruss and Ryder (2003), Burruss and Laughrey (2010), G.E. Claypool and C.N. Threlkeld (USGS, unpublished data, 1977), Dennen and others (in press), Jenden and others (1993), Laughrey and Baldassare (1998), Laughrey and others (2004), U.S. Geological Survey (2009), and Osborn and McIntosh (2010). This worksheet also contains information from published sources augmented with API numbers and location information from the public sources referenced above.

The third worksheet, titled "Abbreviations," is a key for all abbreviations in the database.

\section{Identification Number}

Several identification numbers were included in the data to identify each gas well sample. The field "Unique ID" represents the number assigned by the USGS, whereas the identification numbers under the fields "Sample ID," "U.S. Bureau of Mines ID," "U.S. Bureau of Mines Index No. 1," and "U.S. Bureau of Mines Index No. 2" are identification names and numbers given by published sources.

\section{Location of Gas Samples}

Two sets of latitude and longitude in decimal degrees are provided in North American Datum of 1983 (NAD 83). Samples in which latitude and longitude were reported in a different coordinate system were converted to NAD 83 for consistency. Because location information was not reported for some of the samples included in the database, two sets of latitude and longitude columns, labeled "Latitude from public source," "Longitude from public source," "Latitude from published source," and "Longitude from published source," are provided. A third set, "LATITUDE" and "LONGITUDE" was created to combine the coordinates from public and published sources for GIS and plotting use. All but 49 of the 1,280 analyses have longitude and latitude information; the 49 analyses lacking coordinates are provided for users because they include well names for future geographic referencing.

\section{Geologic Information}

The database also includes available geologic information such as the producing formation, geologic age, and stratigraphic units. Stratigraphic names were checked against the USGS National Geologic Map GEOLEX (2012) database.

\section{Potential Uses of the Database}

As stated previously, the databases can be used to better constrain the areal extent, stratigraphic distribution, composition, and origin of natural gas in the central Appalachian basin. We have used the database to create a series of maps to determine the spatial distribution of the natural gas samples. 
Figure 1 shows the methane content of all of the producing formations (Cambrian to Pennsylvanian) and illustrates the areal extent of the distribution of the samples in the central Appalachian basin natural gas database (appendix 1, "Molecular Compositions" worksheet). The map shows an increase in methane content and a general decrease in higher weight hydrocarbons from west to east as the basin thickens (fig. 1). Separate maps of methane content in Devonian and Silurian strata (figs. 2-3) show a similar pattern but with different areal extents. Figure 4 shows the areal extent and content of carbon dioxide in natural gas samples from all strata. Because stratigraphic information and depth are included in the database, users can create maps of the ranges in natural gas content with producing formation or stratigraphic horizon and depth.

The areal extent of the analyses within the isotopic database (appendix 1, "Isotopic Compositions" worksheet) is shown in figure 5. A cursory examination of the isotopic data shows that $\delta^{13} \mathrm{C}_{1}$ and $\delta^{2} \mathrm{D}$ measurements on $\mathrm{CH}_{4}$ for the 186 samples within the database, which vary in age from Cambrian to Carboniferous, range from -55.1 to $-26.02 \%$ and -315.0 to $-133.1 \%$, respectively. Most of the lower $\delta^{13} \mathrm{C}_{1}$ and $\delta^{13} \mathrm{D}$ values are from the New Albany Shale. Devonian gases have $\delta^{13} \mathrm{C}_{1}$ and $\delta^{13} \mathrm{D} \mathrm{CH}_{4}$ values ranging from -54.2 to $-31.5 \%$ and -315.0 to $-159.0 \%$, respectively, indicating that most of the Devonian gas is thermogenic in origin. 


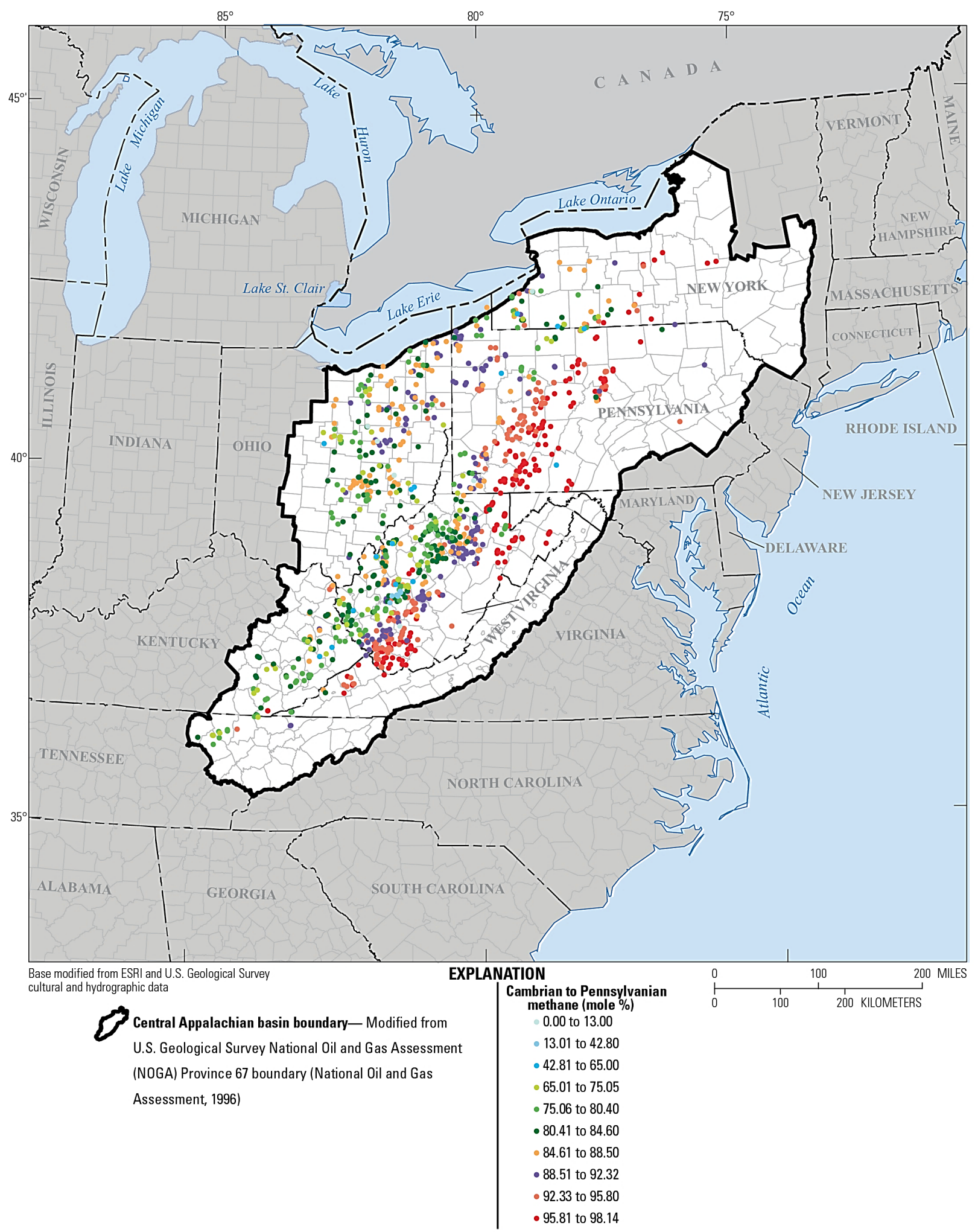

Figure 1. Map of the distribution of methane content in Cambrian to Pennsylvanian natural-gas-producing formations in the central Appalachian basin from the natural gas database. A total of 1,229 methane analyses were used to create the map. 


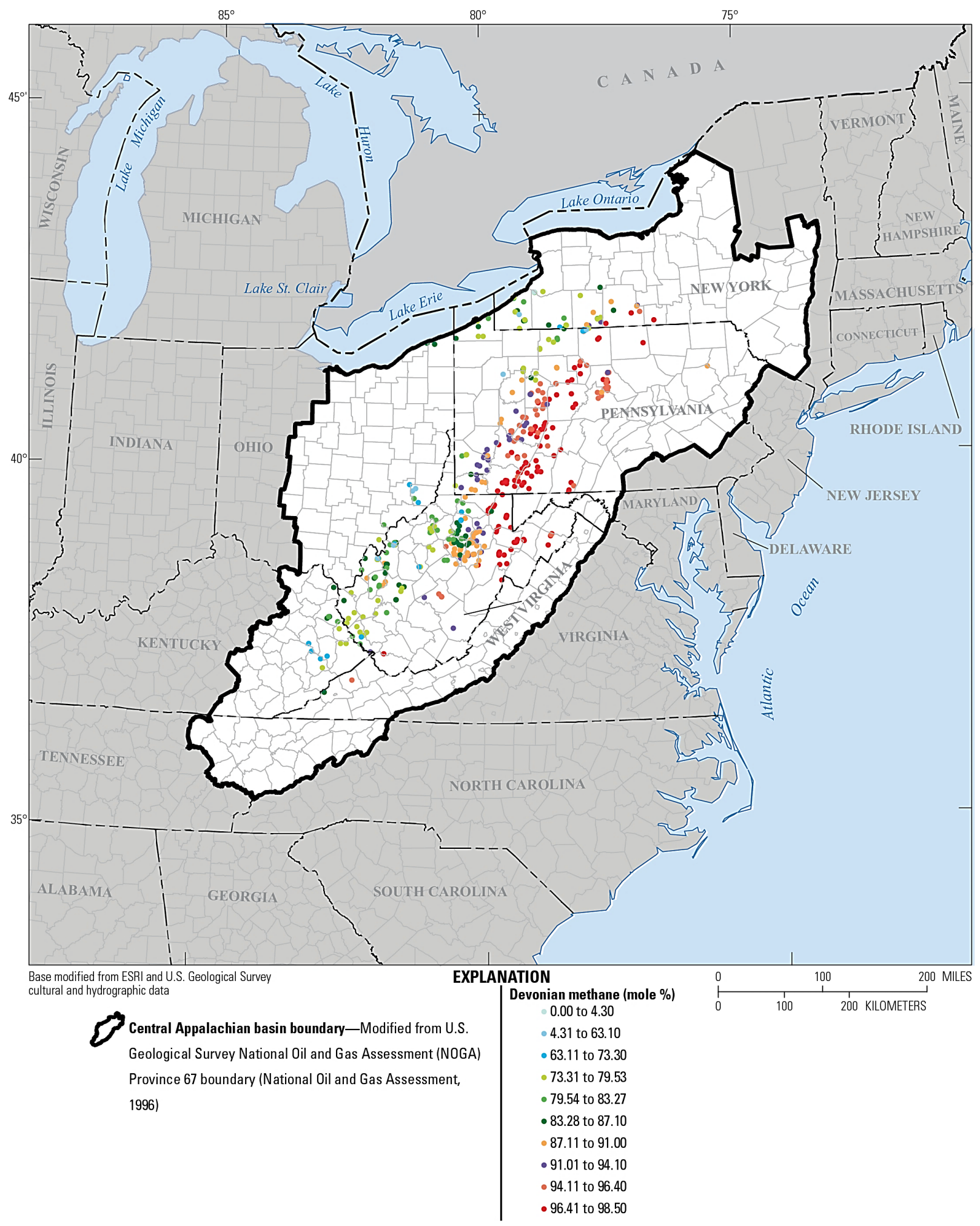

Figure 2. Map of the distribution of methane content in Devonian natural-gas-producing formations in the central Appalachian basin from the natural gas database. A total of 498 methane analyses were used to create the map. In general, methane content increases from west to east where sediments are buried more deeply. 


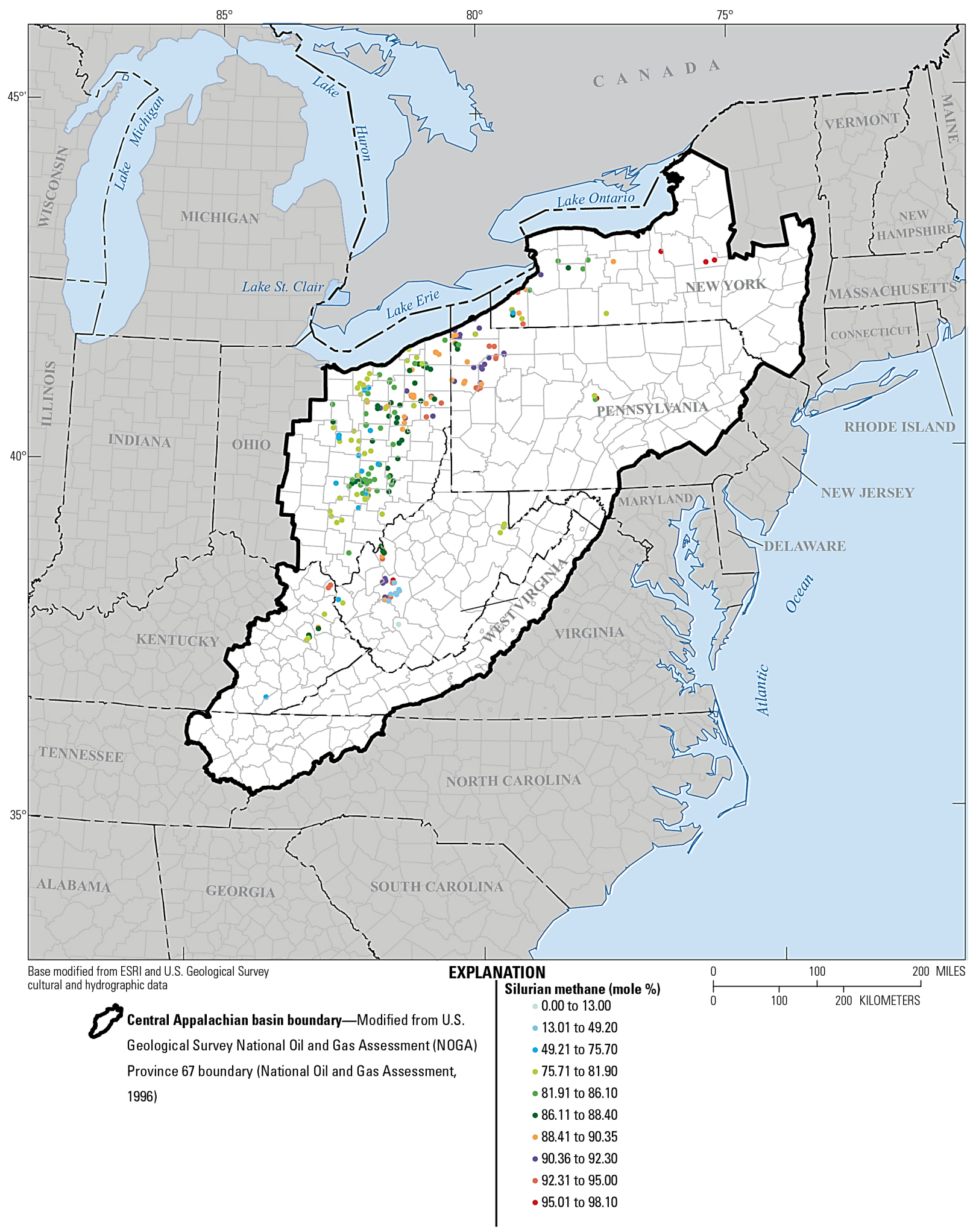

Figure 3. Map of the distribution of methane content in Silurian natual-gas-producing formations in the central Appalachian basin from the natural gas database. A total of 299 methane analyses were used to create the map. 


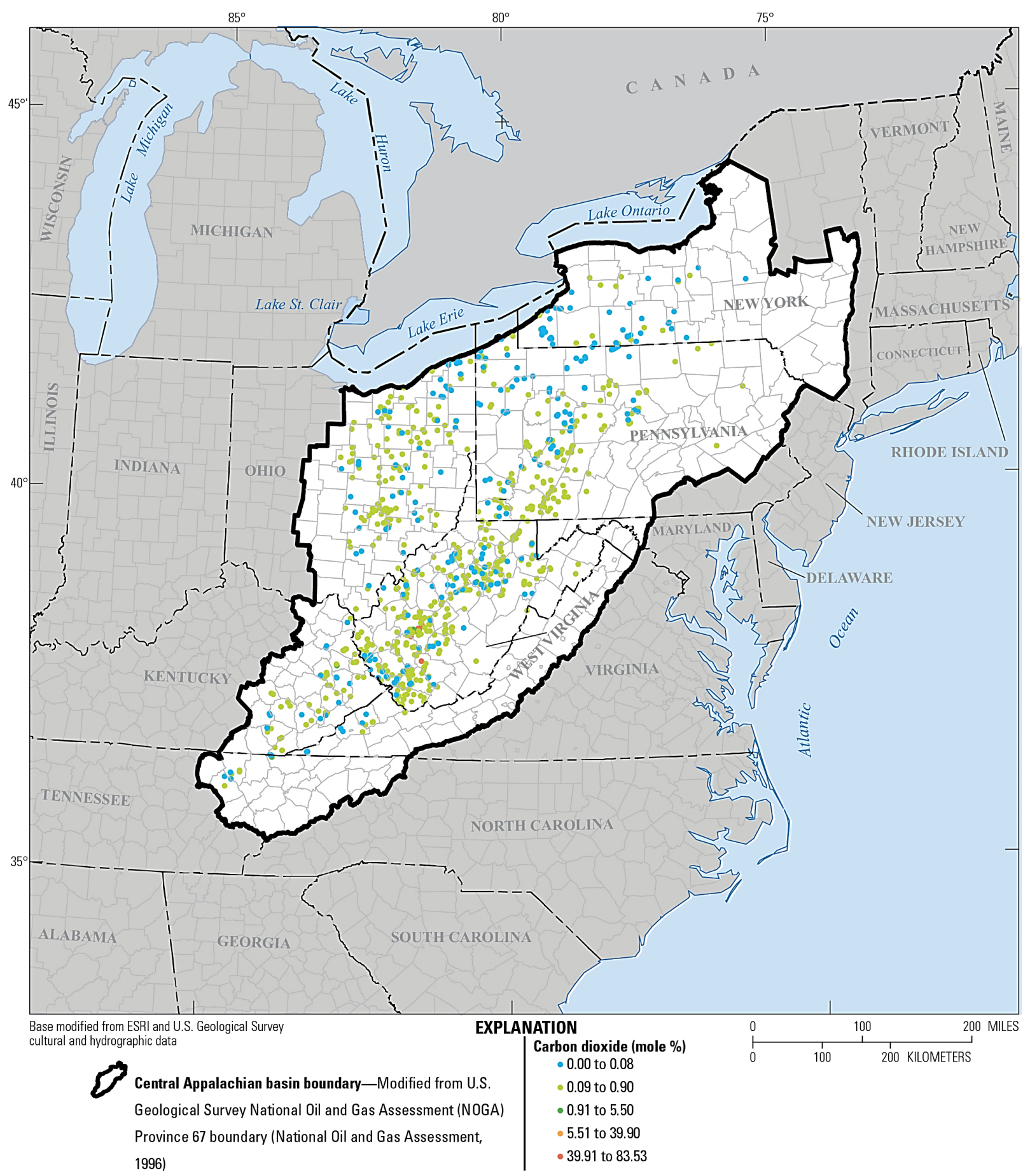

Figure 4. Map of the distribution of carbon dioxide in Cambrian to Pennsylvanian natural-gas-producing formations in the central Appalachian basin from the natural gas database. A total of 991 carbon dioxide analyses were used to create the map. Carbon dioxide contents ranged from 0 to 83.53 mole percent. 


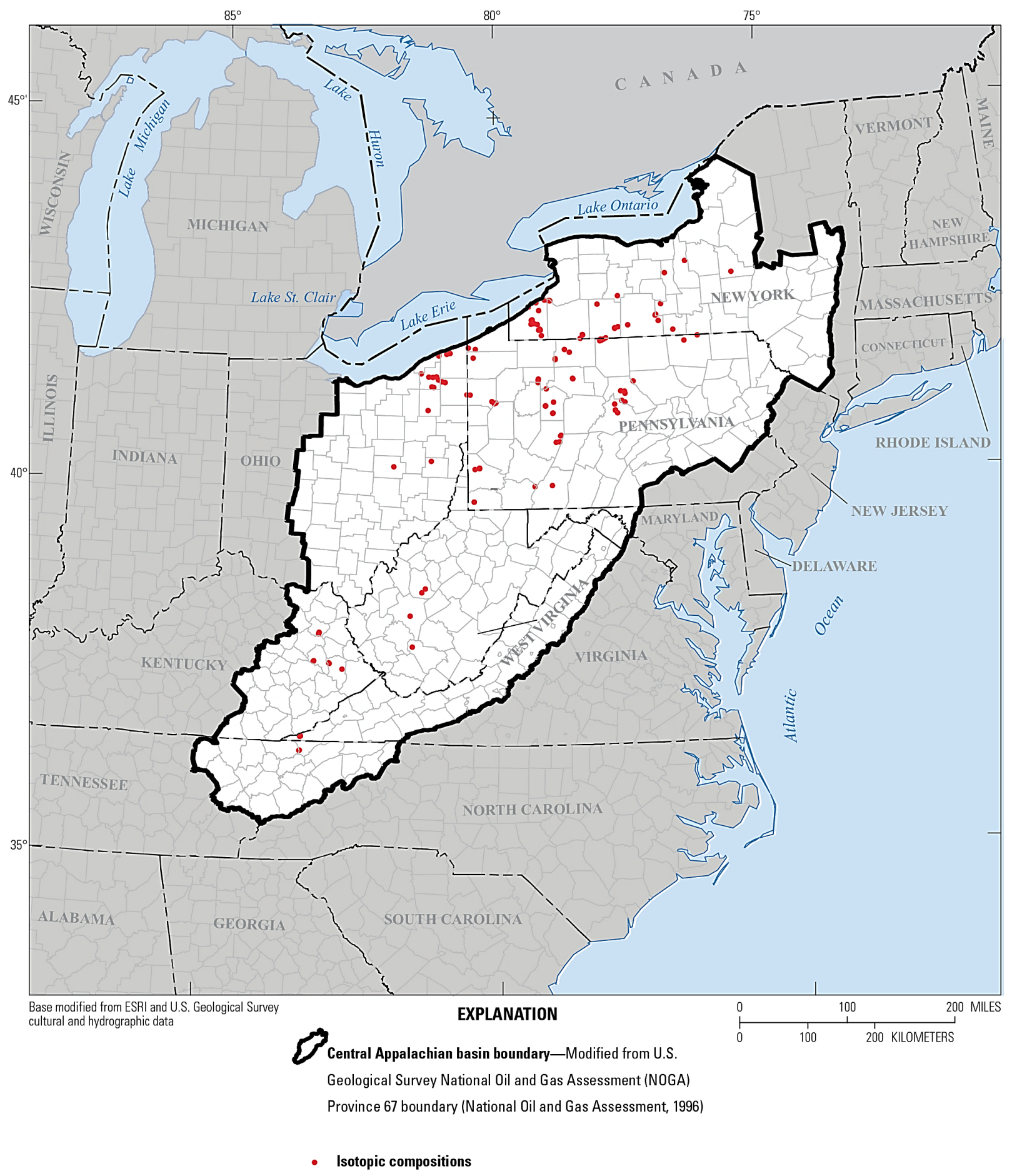

Figure 5. Map of the distribution of isotopic measurements contained in the database. A total of 151 analyses from the database were used to create the map 


\section{Acknowledgments}

The authors would like to give special thanks to Linda Bragg and Robert Ryder (USGS, Emeritus), and Michael Trippi and Christopher Garrity (USGS), for their help and constructive feedback.

\section{References Cited}

Burruss, R.C., and Laughrey C.D., 2010, Carbon and hydrogen isotopic reversals in deep basin gasEvidence for limits to the stability of hydrocarbons: Organic Geochemistry, v. 41, p. 1285-1296.

Burruss, R.C., and Ryder, R.T., 2003, Composition of crude oil and natural gas produced from 14 wells in the Lower Silurian "Clinton" sandstone and Medina Group, northeastern Ohio and northwestern Pennsylvania: U.S. Geological Survey Open File Report 2003-409, p. 64.

Dennen, K.O., Deering, M., and Burruss, R.C., in press, The geochemistry of oils and gases from the Cumberland Overthrust Sheet in Virginia and Tennessee, in Ruppert, L.F., and Ryder, R.T., eds., Coal and petroleum resources in the Appalachian basin-Distribution, geologic framework, and geochemical character: U.S. Geological Survey Professional Paper 1708.

Hamak, J.E., and Gage, B.D., 1992, Analyses of natural gases, 1991: U.S. Bureau of Mines Information Circular 9318, 97 p.

Hamak, J.E., and Sigler, S., 1991, Analyses of natural gases, 1986-1990: U.S. Bureau of Mines Information Circular 9301, 315 p.

Hamak, J.E., and Sigler, S., 1993, Analyses of natural gases, 1992: U.S. Bureau of Mines Information Circular 9356, $62 \mathrm{p}$.

Hertweck, F.R., Jr., and Fox, D.D., 1984, Analyses of natural gases, 1983: U.S. Bureau of Mines Information Circular 8993, 127 p.

Hugman, R.H., Vidas, E.H., and Springer, P.S., 2000, Development of the DOE Gas Information System (GASIS): Final report, Contract Number DE-AC21-93MC28139-23, CD-ROM.

Jenden, P.D., Drazan, D.J., and Kaplan, I.R., 1993, Mixing of thermogenic natural gases in northern Appalachian basin: American Association of Petroleum Geologists Bulletin, v. 77, p. 980-998.

Kentucky Geological Survey, 2012, Kentucky Geological Survey Oil and Gas Well Record System: Available at http://kgs.uky.edu/kgsweb/DataSearching/OilGas/OGSearch.asp.

Laughrey, C.D., and Baldassare, F.J., 1998, Geochemistry and origin of some natural gases in the Plateau province, central Appalachian basin, Pennsylvania and Ohio: American Association of Petroleum Geologists Bulletin, v. 82, p. 317-335.

Laughrey, C.D., Billman, D.A., and Canich, M.R., 2004, Petroleum geology and geochemistry of the Council Run gas field, north central Pennsylvania: American Association of Petroleum Geologists Bulletin, v. 88, p. 213-239. 
Miller, R.D., and Hertweck, F.R., Jr., 1982, Analyses of natural gases, 1981: U.S. Bureau of Mines Information Circular 8890, 84 p.

Miller, R.D., and Hertweck, F.R., Jr., 1983, Analyses of natural gases, 1982: U.S. Bureau of Mines Information Circular 8942, 100 p.

Moore, B.J., 1982, Analyses of natural gases, 1917-80: U.S. Bureau of Mines Information Circular $8870,1,055$ p.

Moore, B.J., and Hamak, J.E., 1985, Analyses of natural gases, 1984: U.S. Bureau of Mines Information Circular 9046, $102 \mathrm{p}$.

Moore, B.J., and Sigler, S., 1986, Analyses of natural gases, 1985: U.S. Bureau of Mines Information Circular 9096, $182 \mathrm{p}$.

Moore, B.J., and Sigler, S., 1987, Analyses of natural gases, 1917-85: U.S. Bureau of Mines Information Circular 9129, 1,197 p.

Moore, B.J., and Sigler, S., 1987, Analyses of natural gases, 1986: U.S. Bureau of Mines Information Circular 9167, $101 \mathrm{p}$.

National Geologic Map Database Geologic Names Lexicon (“GEOLEX”), 2012: Available at http://ngmdb.usgs.gov/Geolex/.

National Oil and Gas Assessment, 1996, 1995 National Oil and Gas Assessment_-One-quarter mile cell data. Available at http://energy.cr.usgs.gov/oilgas/noga/data.html.

New York Department of Environmental Conservation, 2011, New York State DEC Oil and Gas database: Available at http://www.dec.ny.gov/cfmx/extapps/GasOil/search/wells/index.cfm.

Ohio Department of Natural Resources, 2012, Risk-based data management system (RBDMS): Available at http://www2.ohiodnr.com/mineral/OHRbdmsOnline/WebReportAccordion.aspx.

Osborn, S.G., and McIntosh, J.C., 2010, Chemical and isotopic tracers of the contribution of microbial gas in Devonian organic-rich shales and reservoir sandstones, northern Appalachian Basin: Applied Geochemistry, v. 25, p. 456-471.

Pennsylvania Department of Conservation and Natural Resources, 2011, The Pennsylvania Internet Record Imaging System/Wells Information System (PA*IRIS/WIS) — Gateway to detailed oil and gas well information data: Available at http://www.pairis.state.pa.us/Citrix/MetaFrame/auth/login.aspx.

Ruppert, L.F., Fedorko, N., Warwick, P.D., Grady, W.C., Crangle R.D., and Britton J.Q., 2004, Results of coal bed methane drilling, Mylan Park, Monongalia County, West Virginia: U.S. Geological Survey Open-File Report 2004-1402, 44 p. 
Ruppert, L.F.; Trippi, M.H.; Fedorko, Nick; Grady, W.C.; Eble, C.F.; and Schuller, W.A., in press, Results of coalbed methane drilling, Meadowfill Landfill, Harrison County, West Virginia, chap. G.4 of Ruppert, L.F., and Ryder, R.T., eds., Coal and petroleum resources in the Appalachian basinDistribution, geologic framework, and geochemical character: U.S. Geological Survey Professional Paper 1708, $30 \mathrm{p}$.

Sigler, S.M., 1994, Analyses of natural gases, 1993: U.S. Bureau of Mines Information Circular 9400, $58 \mathrm{p}$.

Tennessee Division of Geology, 2008, Electronic oil and gas database, 1 CD-ROM.

U.S. Environmental Protection Agency, 2012, Land-based oil and gas extraction knowledge base: Available at $h t t p: / / w w w . e p a-o t i s . g o v / k n o w l e d g e \_b a s e / o i l a n d g a s /$.

U.S. Geological Survey, 2009, Energy geochemistry data base: Provisional release, available at http://energy.cr.usgs.gov/prov/og/index.htm.

U.S. Geological Survey, 2012, National geological map database: Available at http://ngmdb.usgs.gov/ngmdb/ngmdb_home.html.

Virginia Department of Mines, Minerals, and Energy, 2012, Division of Gas and Oil E-forms center: Available at https://www.dmme.virginia.gov/dgoeforms/frmlog in.aspx.

West Virginia Geological \& Economic Survey, 2012, The West Virginia Geological \& Economic Survey's (WVGES) "Pipeline-Plus": Available at http://www.wvgs.wvnet.edu/pipe2/OGDataSearch.aspx. 


\section{Appendix 1. Natural_Gas_Geochemical_Database_2013}

[Available at http://pubs.usgs.gov/of/2014/1207/.]

The database, in .xls format, consists of three worksheets titled "Molecular Composition," "Isotopic Composition," and "Abbreviations." The Molecular Composition worksheet contains molecular analyses of 1,280 samples of natural gas, characterized in 70 fields. The Isotopic Composition worksheet contains stable isotopic data for 186 samples, described in 48 fields.

The Abbreviations worksheet includes the following, in order, for the Molecular Compositions database: ID = identification number; No. = number; API = American Petroleum Institute number; USGS = U.S. Geological Survey; $\mathrm{ft}=$ feet; psig = pounds per square inch guage; $\mathrm{mcfd}=$ thousands of cubic feet per day; $\%=$ percent; $n$-butane $=$ normal butane; $i$-butane $=$ iso-butane; $n$-pentane $=$ normal pentane; $i$-pentane $=$ iso-pentane; $\mathrm{C}_{1}=$ methane; $\mathrm{C}_{2+}=$ ethane plus higher molecular weight hydrocarbons; $\mathrm{C}_{4+}=$ iso-butane plus higher molecular weight hydrocarbons; $\mathrm{C}_{6+}=$ hexane plus higher molecular weight hydrocarbons; $\mathrm{N}_{2}=$ nitrogen; $\mathrm{O}_{2}=$ oxygen; $\mathrm{Ar}=$ argon; $\mathrm{H}_{2} \mathrm{~S}=$ hydrogen sulfide; $\mathrm{CO}_{2}$ $=$ carbon dioxide; $\mathrm{BTU}=$ British thermal units.

Abbreviations, in order, for the Isotopic Compositions database are the following: ID = identification number; No. $=$ number; API $=$ American Petroleum Institute number; USGS $=$ U.S. Geological Survey; $\mathrm{ft}=$ feet; $\mathrm{m}=$ meters; $\mathrm{BTU}=$ British thermal units; $\mathrm{ft}^{3}=$ cubic feet; $\delta^{13} \mathrm{C}_{1}=\delta^{13} \mathrm{C}$ of methane; \%o = permil; $\delta^{2} \mathrm{HC}_{1}=\delta^{2} \mathrm{H}$ of methane; $\delta^{13} \mathrm{C}_{2}=\delta^{13} \mathrm{C}$ of ethane; $\delta^{2} \mathrm{HC}_{2}=\delta^{2} \mathrm{H}$ of ethane; $\delta^{13} \mathrm{C}_{3}=$ $\delta^{13} \mathrm{C}$ of propane; $\delta^{2} \mathrm{HC}_{3}=\delta^{2} \mathrm{H}$ of propane; $\delta^{13} \mathrm{C} i$ - $\mathrm{C}_{4}=\delta^{13} \mathrm{C}$ of $i$-butane; $\delta^{13} \mathrm{C} n$ - $\mathrm{C}_{4}=\delta^{13} \mathrm{C}$ of $n$-butane; $\delta^{13} \mathrm{C} n-\mathrm{C}_{5}=\delta^{13} \mathrm{C}$ of $n$-pentane; $\delta^{13} \mathrm{C}_{4}=\delta^{13} \mathrm{C}$ of butane; $\delta^{13} \mathrm{CO}_{2}=\delta^{13} \mathrm{C}$ of carbon dioxide; $\delta^{15} \mathrm{~N}=\delta^{15} \mathrm{~N}$ of $\mathrm{N}_{2} ; \delta^{2} \mathrm{H}_{\mathrm{i}}-\mathrm{C}_{4}=\delta^{2} \mathrm{H}$ of $i$-butane; $\delta^{2} \mathrm{H}_{\mathrm{n}}-\mathrm{C}_{4}=\delta^{2} \mathrm{H}$ of $n$-butane; $\delta^{2} \mathrm{H}_{\mathrm{n}}-\mathrm{C}_{5}=\delta^{2} \mathrm{H}$ of $n$-pentane. 
ISSN 2331-1258 (online)

http://dx.doi.org/10.3133/ofr2014-1207 